\title{
MODERN INFORMATION, COMMUNICATION, INTERACTIVE EDUCATIONAL TECHNOLOGIES IN THE SYSTEM OF HIGHER EDUCATION
}

\section{Tetiana Kramarenko ${ }^{1}$ \\ Olena Rezunova ${ }^{2}$}

\section{DOI: https://doi.org/10.30525/978-9934-588-15-0-12}

\begin{abstract}
The use of modern information and interactive technologies in education is one of the most important and sustainable tendencies in the development of the world educational process. In recent years national system of higher education uses computer and other information technologies for studying different subjects. The purpose of the research is to analyze the existing interactive, information and communication educational technologies and to get acquainted with the advantages of their usage by teachers in educational process. The methodological basis of the research forms the principles of scientificity, systematicity and objectivity. The general scientific methods (of analysis, synthesis, comparative, systematization, generalization) have been used when writing the paper. The material has been presented according to the thematic principle. Comparative, typological and functional methods have been used for a comprehensive research of the topic. The article deals with modern information, communication and interactive educational technologies, the advantages of their use by teachers in practical classes at higher school. The basic signs of interactive technologies have been shown: the construction of training based on the student's interaction with the learning environment; the change in the interaction of the teacher and students: the activity of the teacher helps to activate students, and the task of the teacher is to create conditions for their initiative; the role of a teacher as a consultant, organizer, source of information; the absence of the dominance of any participant in training over others. Authors study the most potential and promising types of modern informa-
\end{abstract}

\footnotetext{
${ }^{1} \mathrm{PhD}$ in Pedagogics, Associate Professor, Dnipro State University of Agriculture and Economics, Ukraine ${ }^{2} \mathrm{PhD}$ in Pedagogics, Associate Professor, Dnipro State University of Agriculture and Economics, Ukraine

(C) Tetiana Kramarenko, Olena Rezunova
} 
tion and interactive technologies, which are used in the educational process of higher institutions: chat, internet forum, educational portals, multimedia, role and business games. They help to improve the quality of education, give the opportunities for continuous education, provide adequate level of teachers training, and improve the content of teaching. Modern information technologies and innovative teaching methods give university instructors tremendous opportunities for education, professional growth; they provide access to unlimited information, and give the chance to conduct dialogue with the whole world.

\section{Introduction}

Nowadays, higher education is one of the determining factors of the intellectual and productive forces for society reproduction and for the development of Ukrainians' spiritual culture, the guarantor of the future success in consolidation and strengthening of the authority of Ukraine as a sovereign, independent, democratic, social and law based state.

The process of integration of Europe, its move to the East, is followed up by the creation of general education and scientific area, development of the unified criteria and standards in this field, where the quality of higher education is the basis for the formation of this area.

Over the past two decades, there has been a shift from traditional technology of higher education to «information and communication technologies» - personal computers, computer databases, electronic information networks, etc. Thus, there is a shift to the developments aimed at creating a specific learning environment, or applying technology and communication in education. Information and communication teaching technologies (ICT) in education is a complex of fundamentally new educational and methodological materials, technical, communication and instrumental means of processing, preservation, transmission, display of information in accordance with the laws of the educational process, which effectively influence the professional training of future specialist.

Means of ICT is a synthesis of modern achievements of pedagogical science and means of information and computer technology. They implement scientific approaches to the organization of the educational process in order to optimize it and increase its efficiency, as well as to intellectualize the material and technical base of educational institutions in a continuous way. 
In addition, the effectiveness of the learning process also depends on the introduction of a variety of interactive technologies that ensure the dialogue of the learning process.

Consequently, the relevance of this issue in the modern educational environment is evident, as today qualitative teaching of disciplines cannot be carried out without the use of facilities provided by computer, interactive technologies and the Internet.

The purpose of the research is to analyze the existing interactive, information and communication educational technologies and to get acquainted with the advantages of their usage by teachers in educational process.

According to the goal, the following tasks were set: to reveal the concept of ICT and interactive technologies, to consider the ways of using these technologies by teachers in educational process of higher schools.

Research methods. The general scientific methods (analysis, synthesis, comparative, systematization) have been used while writing the paper. The material has been presented according to the thematic principle. Comparative, typological and functional methods have been used for a comprehensive research of the topic. The theoretical and practical results of implementing information and interactive technologies have been studied using the methods of analysis and synthesis. The method of analysis has been used for a detailed study of information technologies, which made it possible, in particular, to study scientific viewpoints on the need for implementation. The method of synthesis made it possible to distinguish the types of interactive technologies in the system of higher education.

\section{Operational definition of terms "technologies", "information and communication technologies" "interactive technologies", and their advantages (ICT)}

Historically, the concept of technology has emerged in connection with the technical process and according to vocabulary interpretations (techneart, craft, science, logos - concept, teaching) is a set of knowledge about methods and means of materials processing. Technology also includes the art of mastering the process, resulting in personification. The technological process always requires a certain sequence of operations using the necessary means (materials, tools) and conditions. Technology in procedural sense answers the question: «How to make, with what and by what means?» 
$[12$, p. 7]. Existing features of technology include standardization, unification of the process and the possibility of its implementation in relation to the given conditions.

The analysis of the psychological and pedagogical literature shows that scientists have different interpretation of the studied phenomenon. Information and communication technologies, including the computer, which can manage cognitive activity, are a collection of computer-oriented methods, tools and organizational forms of learning. Very often the term «information and communication technologies» is associated with the term «computer-oriented technologies» [24]. ICT is regarded as a means of realizing the global tasks of reforming higher education, the mean of "the personal development and creative potential..." [25, p. 14]; information technology based on personal computers, computer networks and communications that have a favorable user environment [19]; "The methodology and technology of the educational process using the latest electronic learning tools, and, first of all, computers» [11, p. 32]; "A set of software, technical, computer and communication tools, methods and innovative methods of their application to ensure high efficiency and informatization of the educational process»» [13, p. 30]; a system of methods for entering, processing, storing, retrieving and transmitting information on computer networks [14]. We emphasize that the term «communication» and «information» characterizes the concept of this term, the dual nature of technology - information content (information environment) and communication capabilities (communication tool). Scientists characterize this technology as a subject-oriented and communicatively oriented learning environment included in the educational activity.

Information and communication technology (ICT) is often used as a synonym for information technology (IT), although ICT is a more general term emphasizing the role of unified technologies and the integration of telecommunications (telephone lines and wireless telephony) connections, computers, software, storage and audiovisual systems that allow users to create, access, store, transmit and modify information. In other words, ICT consists of IT as well as telecommunications, media broadcasts, all types of audio and video processing, transmission, network management and monitoring functions [18, p. 5].

So, information and communication technologies is a set of methods, production processes and software tools integrated for the purpose of col- 
lecting, processing, storing, distributing, demonstrating and using data for the benefit of their users [18, p. 7].

Interactive technologies are collaborative studying when both students and teachers are the subjects of the educational process. Interactivity can be highlighted as the ability to interact, study in conversation, dialogue, action. So, in the narrow sense, interactive ones can be called technologies in which the learner is a participant. He does not act only as a listener, an observer, but takes an active part in what is happening, actually creating this phenomenon [12].

The main advantages of interactive technologies include:

- helping students learn how to express their own opinions; to analyze the information received; to use the knowledge and experience acquired earlier; to debate, to defend their own point of view; to be more confident and independent;

- facilitating the intensification and optimization of the educational process. The goal of interactive learning is to create comfortable conditions and a supportive atmosphere in which each student will feel successful in learning and feel his or her intellectual ability.

The main features of interactive technologies are:

- the development of training on the interaction of the student with the learning environment, which serves as a space for learning experiences;

- a change in the interaction of the teacher and students: the activity of the teacher gives way to the activity of students, and the task of the teacher is to create conditions for their initiative;

- role of the teacher as a consultant, organizer, source of information;

- absence of the dominance of any participant in training over others [6].

\section{Information and communication technologies in the system of higher education}

Any pedagogical technology is information technology, because the basis of the learning technological process is the receiving and transformation of information.

The information and communication technologies in education are aimed at boosting mental activity, developing creative abilities and forming a dialogue. In turn, ICTs are tools for creating, storing, transmitting, processing information and managing it. This widely used term includes all the 
technologies used to communicate and work with information. Appropriate use of ICT in the educational process is a prerequisite for improving the quality of educational services, expanding their capabilities, and creative implementation of personality in learning activities [22, p. 7].

Information and communication technologies have great potential in education and contribute to the implementation of such didactic tasks:

- improvement of the quality of education on the basis of the interconnection of the general and didactic principles of autonomy, activity and systematic character;

- expansion of opportunities for continuous education based on the implementation of the principles of consistency, continuity and accessibility;

- providing adequate level of teachers training for work with information and communication technologies;

- improvement of the content of teaching, taking into account the interaction of general and didactic principles, covering the principle of scientific research, visibility, accessibility, communication theory with practice;

- continuous improvement of the didactic provision of the educational process $[22$, p. 8$]$.

We researched the following types of the information and communication technologies: chats, online forums and educational portals.

Chat (means «talk) is one of the technologies of synchronous dialogue that occurs in real time and almost without delay. At the same time, two interlocutors are simultaneously at their computers and, using special software, instantly send each other small written phrases, short messages that are created in the format of ordinary, live dialogue. To have a real-time online dialogue IRC (Live Chat Online) can be used. It offers a wide variety of options that differ from a simple chat. To communicate with channels (groups or rooms), it is advisable to have a dedicated IRC client program that allows to have multiple channels of dialogue, including private chat between two people.

By type of network communication, text (web-chats), voice and video chat are distinguished. Web chats (text) are special Internet services, text messaging, which is possible in two variants: public and private. The servers contain a special set of technical programs that allow a large number of interlocutors to have a dialogue, while working with a familiar Internet Explorer (Internet Explorer). Web chats can be used if you want to chat with many people 
on different topics. Interactive computer conversations (chats) require careful planning, specialized computer programs, and compliance with ethical standards and communication procedures. Virtual messengers need to have a microphone or headset with microphone for voice messaging. Such chats are often used during group play, providing lively dialogue between team members. Voice chats are used for webinars (voice training seminars). Video chatVoice chat with live video chat. They are used during business conferences when one or more of its participants cannot attend the general meeting.

Web-chats can be considered as a classic communication process. The use of them in the educational process contributes to the formation of students' communicative skills, dialogue [15]. The above confirms that instant messaging (chat) technologies perform educational, communicative functions and are appropriate in the process of forming a professional dialogue culture for students.

Online forums provide active participation in the discussion. Today, the Internet is regarded as an integral part of the life of a modern expert, as there is no alternative source of information that would enable communication with representatives of other countries and form a favorable basis for dialogue between cultures [2, p. 43-44]. In the online forum, each participant can read the full text of the discussion and join the discussion. The analysis of discussions in Internet forums and thematic groups gives an opportunity to reveal the development of the skills in tolerant communication, professional dialogue, argumentation of their position, etc. [22].

Many researchers emphasize the advisability of student participation in the following forums: http://forum.osvita.org.ua/ (you can discuss and express your own views on any issues related to higher education, second higher education, distance education, education abroad; discuss issues related to published articles, results of conferences, etc.); Univer-sity (http://www.univer-sity.com) (students have the opportunity to discuss various topics: universities and faculties, study abroad, student news, travel, literature, Internet, politics, economy, business, etc.

So, online forms help to develop dialogue skills, to participate in the discussion, to conduct tolerant dialogue, give students the opportunity to discuss different professions, discuss different topics.

Educational portals are a software and technology complex whose main task is to accumulate data on scientific and methodological information resources, 
state educational standards, modern technologies of teaching, information that supports the personal level of education and its constant improvement.

The general characteristics of portals are provided by N. Zadorozhnyi and T. Omelchenko [23], who view the portal as an entrance (or exit) to the global information space. The main characteristics of the portals include: existence of a developed system of information resources; active interaction with users through the forum system; the presence of centralized input and special means for convenient use of information resources.

Educational portals include specialized services that provide access to various electronic educational resources (e-libraries, e-learning courses, knowledge testing systems, etc.) [1].

Thus, educational portals facilitate effective dialogic interaction between students and teachers in the process of searching necessary professionally oriented information, allow to organize and implement mediated dialogue in the educational process using the latest technologies, ensure constant access of students to teaching materials, lists and recommended literature, provide the opportunity to organize virtual consultations and seminars.

\section{Interactive learning technologies in the system of higher education}

At the present stage, training of future specialists requires active forms and methods of teaching. The term «interactive» has two components: inter and $a c t$, that is, the ability to interact. Therefore, it is assumed that the educational process is subject of continuous, active interaction of all participants. Interactive learning is based on cooperation, which is based on the «pedagogy of cooperation: the direction of pedagogical thinking and practical activity, the purpose of which is the democratization and humanization of the pedagogical process» [3, p. 43].

The purpose of interactive learning is to create such comfortable conditions for each student to feel his or her intellectual capacity to learn new things. This can be achieved only with constant active interaction of the teacher and students. Interactive learning involves enhancing students' learning opportunities instead of receiving and retrieving ready-made information. Classes, where interactive technologies are used, enrich students with basic knowledge and skills, which are crucial to the development of individual competencies. They capture, arouse interest and teach indepen- 
dent thinking. The effectiveness and power of influencing the emotions and consciousness of students depends on the skills and style of the teacher.

During interactive learning student becomes subject of study, he feels himself like an active participant in the process of his own education, personal and professional development. This provides an intrinsic motivation for learning that contributes to its effectiveness.

It is necessary to follow the principles of interactive learning, namely:

1. The principle of activity, which means that each student must participate actively in the process of communication and interact actively with other students.

2. The principle of open feedback, the essence of which is the mandatory expression by a member or all members of a group their opinions, ideas or objections of the tasks. Thanks to the feedback, team members learn how others perceive their communication and thinking style, and behavior. This principle corrects speech and behavior.

3. The principle of experimentation involves active searching for new ideas and ways for students to solve their tasks. This principle is very important both as an example of the behavior in real life, and as an impetus to the development of creativity and initiative of the individual.

4. The principle of trust in communication. This is the purpose of a special organization of group space during the course in order to change the stereotype of the student and the idea of how the classes should be organized and which role should be played by the teacher.

5. The principle of equality. It means that the teacher does not seek to bind the student their thoughts, but acts with them. In turn, the student is able to play the role of organizer, leader [12, p. 5].

National and international experience shows that interactive technologies contribute to the intensification and optimization of the educational process. They allow students to:

- analyze educational information, learn educational material creatively and therefore, make knowledge more accessible;

- formulate own opinion, express it correctly, prove own point of view, argue and discuss;

- learn to listen to another person, respect alternative thoughts;

- model different social situations, enrich own social experience through inclusion in different life situations; 
- learn to build constructive relationships in a group, determine their place in it, avoid conflicts, solve them, seek compromises;

- develop skills of project activity, independent work, performance of creative works.

- carry out project activity, realize creative ideas, develop skills of independent work [21].

The most potential and promising types of interactive technologies that should be used in the educational process of higher institutions are multimedia technologies and role and business games.

Multimedia technology is a very promising area of technology in the field of education. In the broad sense, «multimedia» means a range of information technologies that use a variety of software and hardware to influence the user most effectively (which has become both a reader and a listener and a viewer). Due to the application of graphic, audio (audio) and visual information in multimedia products and services, these tools have a high emotional charge and attract the attention of the user (listener).

Experiments showed that the listener perceives and is able to process up to one thousand conventional units of information per minute during oral presentation, but in connection with the organs of vision to 100 thousand such units [4]. So, it is absolutely obvious the high efficiency of using multimedia tools in teaching, the basis of which is visual and auditory perception of the material.

The latest developments in computer-based training are called multimedia. The multimedia technologies include animation graphics, videos, sound, distance access and external resources, database management est. Various information components that are run by one or more special programs are called multimedia systems.

The purpose of video and other multimedia tools application during educational process is its visualisation.

The basic principles of video creation are:

- illustrativity (give the teacher an opportunity to illustrate the lessons);

- fragmentation (allows to give the material step by step, depending on the speed of students perception);

- methodical invariance (video clips can be used at different stages of the lesson, pursuing different methodical goals);

- conciseness (presenting more information in less time and more efficiently). 
Among the vast variety of educational multimedia systems, we can conditionally distinguish the most effective tools: computer simulators; automated training systems; educational films; multimedia presentations; video demonstrations [20].

Multimedia learning tools used in the educational process must meet the system of psychological, didactic and methodological requirements.

Specific didactic requirements include:

- adaptability to individual student's capabilities;

- interactive learning;

- realization of computer visualization of educational information;

- development of the student's intellectual potential;

- the systematic, structural and functional coherence of the educational material;

- ensuring the integrity and continuity of the didactic cycle of training.

Didactic requirements closely connected with methodological requirements. Methodological requirements for multimedia learning tools take into account the peculiarity and features of a particular subject, the specifics of the relevant science, its conceptual apparatus [16].

Multimedia training tools must be selected to meet the following methodological requirements:

- educational material should be based on the interconnection and interaction of conceptual, imaginative and effective components of thinking;

- giving the student an opportunity to do various training tests.

Along with the didactic and methodological requirements, there are also a number of psychological requirements that affect the success and quality of multimedia [10].

The main hardware of multimedia technology is a computer equipped with the necessary software and a multimedia projector. Of course, the computer does not replace the teacher, but is only a means of teaching, his assistant.

Due to their capabilities and the development of technical means, multimedia technologies can be used for teaching almost all subjects.

Role and business games promote positive motivation for learning process, increase students interest. The game allows seeing successes, not to notice failures. Conversely, success leads to victory, victory to motivation; motivation promotes the desire to win and to be successful. 
A business game is a simulation of real activity in a specially created problem situation. It is a mean and method of preparing and adapting for professional activities and social contacts [9], method of active learning, which contributes to the achievement of specific tasks, structuring the system of business relations of participants. Its structural elements are the design of reality, the conflict of the situation, the activity of the participants, the appropriate psychological climate, interpersonal and intergroup communication, the solution of problems formulated at the beginning of the game.

A business game is a complex, multifunctional action, in which several interrelated activities are combined: analysis and search for problems solutions, training, development, research, consulting, and formation of team activity. So, business games make educational process closer to real life and develop practical skills [9].

Traditional business games have a scenario, focused on solving typical problem situations, their goal is to teach game participants to solve these problems optimally. In the educational process, the business games are used to consolidate the knowledge that the student gained in the course of lectures, seminars and practice.

Application of business games during training allows to close the educational process to practical activity, to take into account the realities of the present, to make decisions in the conflict situations, to defend their proposals, to develop teamwork, to get results in a limited time. In specially created conditions, the students «worked out» a variety of life situations that allow them to defend their positions.

The main advantages of role and business games compared to traditional methods are an ability to solve problems in a short period of time; an ability to test students' knowledge directly, an ability to increase interest of the participants, and consequently, to increase effectiveness of learning.

The business game, simulating a particular situation, makes it possible to solve specifically formulated tasks and problems, to develop methods of solving problems. It has a rigid structure and rules; its main function is to develop skills and ability to act in standard situations. The role and business game are used to learn new and consolidate old material, because it allows students to understand and learn the material from different positions.

Typically, a business game consists of the following stages: 
- familiarizing the game participants with the purpose, tasks and conditions of the game;

- instruction on the rules of the game;

- formation of working groups by participants of the game;

- analysis, evaluation and conclusions of game results.

On the first stage, preparatory, the choice of the game is justified, determined the goals and objectives of the game, formulated a problem situation, developed a game scenario, prepared information and methodological material.

The second stage the rules of the game and the functions of the players are considered.

The third stage depends on the content and form of a particular game and consist in discussing the problems posed by the participants, making generalized decisions, and analyzing them.

Different types of business games are used in educational process: simulation, operating, role-playing, business theater and intellectual games.

Simulation Games. At the lessons, they simulate the activities of a particular organization, enterprise, educational institution, etc. Also they can simulate events, specific activities of people (business meeting, discussion of the plan) and conditions in which the event takes place (meeting room, office of the head). The scenario of the simulation game, in addition to the plot of events, contains a description of the structure and purpose of the processes and objects that imitate them.

Operating Games. They help to accomplish specific operations, such as the methods of organizing and holding meetings, conferences, etc. Games of this kind are conducted in conditions that simulate reality.

Role games. They work out tactics of behavior, actions, functions and responsibilities of a particular person. For role-playing games, a model-play of the situation is developed, with the distribution of roles between participants.

Business Theater. It is played some situation and behavior of the person in this situation. The student has to mobilize all his experience, knowledge, skills, be able to fit into the image of a certain person, understand his actions, assess the situation and find the right course of behavior.

The main task of staging method is to teach students to navigate in various circumstances, to give an objective assessment of their behavior, to take 
into account the opportunities of other people, to establish contacts with them, to influence their interests, activities.

Culture at the turn of the millennium is a culture of dialogue. First, the cause of the dialogue is cognitive and emotional interest, that is, it performs an informational function in the broad sense of the word. Second, the dialogues involve interaction. This is how the communicative function is carried out.

That is why the use of debate as a kind of intellectual game is intended to help students to develop the skills they need to be successful in today's society. Today, debate is widespread in schools and universities around the world. Most European countries have debate programs at each institution.

The purpose of the debate game is to increase students' level of knowledge. And so it is necessary to participate in the debate in order to learn something. In other words, in the debate, the learning process is more important than the end result of each game - winning or losing. Playing «debate» has allowed to develop one of the most important traits of personality - curiosity.

The students, who play the debate, learn to think logically and critically, to convey their thoughts and views to others or to a wide audience.

Students benefit greatly from the debate. Participants turn from team players into true friends working together to prepare for the debate.

During the debate, it is necessary to listen carefully to opponents in order to understand their position more clearly, but also the strengths and weaknesses of the team. In debating the ability to listen is very important because those players who are unable to listen do not always understand the weakness of their opponents' arguments.

The success of the debate depends on team activity. As in any game, everyone has a role and responsibility, but the team has to work together to help and complement each other.

Thus, the use of intellectual games allow students to acquire knowledge not in the traditional everyday way, but in a game form. In intellectual games, knowledge is an important tool for solving life's problems because they are associated with success in life, and success is victory.

The use of business games as active teaching methods, provides creative activity of students, create conditions for increased motivation and emotionality, and develop critical thinking. 


\section{The development of teachers' practical skills for implementation of interactive, information and communication technologies}

Conversations with teachers of higher educational establishments have shown that they almost do not offer students educational tasks that would force them to use means of information and communication technologies with classmates, teachers, specialists. The reason for this situation is, first of all, their own uncertainty in their abilities to organize constant communication with students.

So, a large number of teachers need assistance in the implementation of interactive, information and communication technologies, their organizational and methodological support. Most of the teachers do not use these technologies and therefore need to be trained. Thus, educational and methodological seminars for university instructors were developed and implemented with the theme «Modern Interactive, Information and Communication Technologies in education», the purpose of which was to prepare teachers to work with interactive, information and communication technologies in the learning process.

A scientific and practical seminar «Pedagogical skills: professional professionalization and innovative approaches» was conducted, the task of which was to increase the teacher's teaching skills. The workshop included lectures ( 8 hours), practical classes ( 8 hours), training sessions (6 hours), master classes (4 hours). Various issues were discussed at the seminar, namely, modern teaching technologies, teaching methods for individual courses, training format as a method of activating at higher educational establishments. The workshop covered issues related to the methodology for conducting projects: information (aimed at collecting specialized information, familiarizing project participants with this information, analyzing it and summarizing facts intended for a wide audience); informational and communicative (found in the harmonious combination of information seeking and communicative activities of students); brain storming, case method analysis, incident method, presentation, role plays, didactic games, etc. [17].

In addition, teachers were invited to take part in the practical organization of professional dialogue with students, enabling them to identify themselves in various situations requiring professional dialogue. During the work the following issues were considered: 
- professional dialogue of teachers who carry out the training process for future merchants;

- formation of a professional dialogue culture of future specialists by means of information and communication technologies;

- the theoretical basis of interactive technologies;

- a methodology for organizing student work on the basis of interactive technologies, taking into account information and communication technologies. Teachers were interested in combined classes with the use of situational tasks, where they demonstrated their pedagogical skills. Teachers shared impressions and ideas, held a dialogue on professional topics.

During the seminar, the attention of teachers was emphasized on the importance of establishing subject and subject relations in the systems «student - student», «student - teacher» and ensuring their pedagogical interaction. The teachers' focus was on developing professional relationships with students based on a polite attitude towards each other, manifestation of moral and social responsibility, ethical conduct, and B. Franklin's rule of «honesty - the best policy» in conducting direct and indirect professional dialogue. During the academic year, the teachers became participants in scientific and methodological seminars «Communicative Processes in Education», «Interactive Technologies for Professional Communication Training». Attention of teachers was focused on such issues as professional dialogue: the essence, functions, types; professional language and speech; non-verbal aspects of intercultural dialogue and their role in regulating relationships, establishing contacts with specialists who are representatives of other cultures; characterization of non-verbal channels of intercultural communication (facial expression, touch, gesture, interpersonal communicative space, visual interaction, intonation); the role of multi- and hypermedia technologies, information retrieval systems in preparing future professionals for a professional dialogue; computer communications in off-line and on-line communication modes; personally oriented technologies of teaching students and their role in communicative training of future specialists, etc. Teachers were introduced to the advantages of the following Internet sites: http://www.teachnology.com - lesson planning; http://www.eslcafe.com an interactive communication club; Global virtual classroom http: //www. virtual- classroom.org - free online educational program; http://teenadviceonline.org - Educational site for teachers. Teachers focused their atten- 
tion on the peculiarities of establishing partnerships with students based on cooperation, openness, trust, personal involvement, support; organization of constant counseling; taking into account the initial knowledge of students in order to model the individual approach to pedagogical interaction; the creation of successful learning situations (the selection of dual tasks, the promotion of intermediate actions, differentiated help), the effect of novelty, the effect of imagination, the effect of change, the effect of the game. Attention of teachers was paid, first of all, to increase the motivation of students' training, which is the driving force in realizing the needs of the individual in the active interaction.

\section{Conclusions}

All of the above makes it possible to conclude that the use of modern information, communication and interactive educational technologies in the educational process has provided a number of advantages, namely:

- provided a high level of interactivity between the students and the material;

- provided the opportunity to develop and improve various learning styles and interactions;

- promoted motivation and encouragement of students.

In addition, the use of modern information, communication and interactive educational technologies makes it possible to improve the students learning abilities and skills, increase students' independency and creativity. These technologies attract students with the novelty and the opportunity to develop themselves. They reveal the joy of learning, the world of intelligence, creativity and future.

Teachers realized that positive learning motivation should ensure not only the content of learning, but also properly organized communicative activities of students through interactive, information and communication technologies. Thus, the teachers tried to actualize the needs of students in the implementation of active professional dialogue, interaction; to form the motives of communication in a professionally directed electronic environment, to realize the possibilities of this environment for the exchange of professionally directed information among specialists; to form the students desire to deepen their knowledge and skills, information and communication tools, improvement of skills in working with information and commu- 
nicative technologies, development of a critical attitude to the results of their activities, etc.

So, it should be noted that modern information technologies and innovative teaching methods give university instructors tremendous opportunities for education, professional growth; they provide access to unlimited information, and give the chance to conduct dialogue with the whole world. Taking part in scientific and methodological seminars, teachers have the opportunity to improve their abilities and pedagogical skills with the help of modern information and communication technologies, to find an individual style of work with students.

\section{References:}

1. Belyaeva A.P. (1995). Professionalno-pedagogicheskaya tekhnologiya obucheniya $\mathrm{v}$ professionalnykh uchebnykh zavedeniyakh [Vocational education technology in vocational schools]. Saint Petersburg: Institute protech education RAO. (in Russian)

2. Demydenko O.P. (2007). Vykorystannia Internet-resursiv u protsesi formuvannia sotsiokulturnoi kompetentsii studentiv VNZ na zaniattiakh $\mathrm{z}$ anhliiskoi movy [Use of Internet resources in the process of formation of sociocultural competence of university students in English classes]. Proceedings of Mizhnarodnoi naukovo-praktychnoi konferentsii «Inozemna mova yak faktor vkhodzhennia $v$ mizhnarodnyi osvitnii prostir» (Ukraine, Uman, 16 June, 2007), pp. 43-44.

3. Honcharenko L.A., Kuzmenko V.V. (2006). Formuvannia polikulturnoi kompetentnosti vchyteliv zahalnoosvitnoi shkoly [Formation of multicultural competence of teachers of secondary school]. Kherson: RIPO. (in Ukrainian)

4. Ivanov V.F., Meleshchenko O.K. (2006). Suchasni kompiuterni tekhnolohii i zasoby masovoi komunikatsii: aspekty zastosuvannia [Modern computer technologies and communications: aspects of application]. Kyiv: IZMN. (in Ukrainian)

5. Korotkov A.M. (2004). Teoretyko-metodycheskaia systema podhotovky uchashchykhsia k obuchenyiu v kompiuternoi srede [Theoretical and methodical system of preparing students for learning in a computer environment] ( $\mathrm{PhD}$ Thesis), Volhohrad. (in Russian)

6. Kovalenko O. (2003). Kontseptualni zminy u vykladanni inozemnykh mov $\mathrm{u}$ konteksti transformatsii inshomovnoi osvity [Conceptual changes in the teaching of foreign languages in the context of the transformation of foreign language education]. Foreign languages at educational establishments. Pedagogical press. (in Ukrainian)

7. Kramarenko T.V., Rezunova O.V. (2016). Vykorystannia Internetu ta elektronnykh osvitnikh resursiv u navchalnomu protsesi vyshchykh navchalnykh zakladiv [Use of the Internet and electronic educational resources in the educational process of higher education institutions]. Visnyk Dnipropetrovskoho universytetu im. A. Nobelia. Seriia «Pedahohika i psykholohiia», vol. 1, no. 11, pp. 251-255. 
8. Kushchenko O.S. (2008). Formuvannia kultury Internet-komunikatsii maibutnikh uchyteliv zasobamy informatsiino-komunikatsiinykh tekhnolohii [Formation of future teachers' Internet communication culture by means of information and communication technologies] (PhD Thesis), Dnipropetrovsk.

9. Ortynskyi V.L. (2009). Pedahohika vyshchoi shkoly [Pedagogy of high school]. Kyiv: Centre of learning literature. (in Ukrainian)

10. Pidlasyi I.P. (1995). Praktychna pedahohika abo try tekhnolohii [Practical pedagogy or three technologies]. Kyiv: Slovo. (in Ukrainian)

11. Polikarpov V.S. (1995). Lektsii z istorii svitovoi kultury [Lectures on the history of world culture]. Kharkiv: Osnova. (in Ukrainian)

12. Pometun O. (2003). Suchasnyi urok: Interaktyvni tekhnolohii navchannia [Modern Lesson: Interactive Learning Technologies]. Kyiv. (in Ukrainian)

13. Pryima M.S. (2005). Formuvannia tekhnolohichnoi kultury maibutnikh uchyteliv informatyky u protsesi profesiino-pedahohichnoi pidhotovky [Formation of technological culture of future teachers of informatics in the process of professional training]. Melitopol. (in Ukrainian)

14. Rotmistrov N.D. (1994). Multimedia v obrazovanii [Multimedia in Education]. IT and Education, no. 4, pp. 89-96.

15. Rozina I.N. (2005). Pedagogicheskaya kompyuterno-oposredovannaya kommunikacziya [Pedagogical computer-mediated communication: theory and practice]. Moscow: Logos. (in Russian)

16. Ryzhenko S.S. Pro dosvid vykorystannia multymediinykh tekhnolohii $\mathrm{u}$ navchalnomu protsesi ( $\mathrm{u}$ VNZ) [About the experience of using multimedia technologies in the educational process (in HEE)] (electronic journal). Available at: http://www.nbuv.gov.ua/ejournals/ITZN/em11/content/09rssseh.htm

17. Schmitz H.-G. (2005). Brainstorming - Made by us. Sprachnachrichten, no. 1 , pp. 11-12.

18. Shvachych H.H., Tolstoi V.V., Petrechuk L.M., Ivashchenko Yu.S., Huliaieva O.A., Sobolenko O.V. (2017). Suchasni informatsiino-komunikatsiini tekhnolohii [Modern information and communication technologies]: Navchalnyi posibnyk. Dnipro: NMetAU. (in Ukrainian)

19. Tekhnolohii navchannia: informatsiini tekhnolohii navchannia [Teaching and assessment: information technology training]. Ukrainian Pedagogics (electronic journal). Available at: http://ukped.com/skarbnichka/2367-tehnologiyinavchannja-informatsijni-tehnologiyi-navchannja.html

20. Tukalo M.D. (2010). Multymediini sytemy navchannia yak novyi metodolohichnyi zasib interaktyvnoho navchannia na urokakh khimii [Multimedia learning systems as a new methodological tool for interactive learning in chemistry lessons]. Informatsiini tekhnolohii i zasoby navchannia [Information technologies and educational tools], no 5(19), p. 25.

21. Vakhrushcheva T.Yu. (2007). Interaktyvni tekhnolohii navchannia yak zasib aktyvizatsii navchalno-piznavalnoi diialnosti [Interactive learning technologies as a means of activating learning and cognitive activity]. Novi tekhnolohii navchannia [New educational technologies]. Kyiv, no 47, pp. 64-69. 
22. Volkova N.P. (2006). Teoretychni ta metodychni zasady pidhotovky maibutnikh uchyteliv do profesiino-pedahohichnoi komunikatsii [Theoretical and methodological foundations of preparing future teachers for vocational-pedagogical communication] ( $\mathrm{PhD}$ Thesis). Luhansk: Luhansk national pedagogic university.

23. Zadorozhna N. (2007). Analiz suchasnoho stanu elektronnykh naukovykh fakhovykh vydan [Analysis of the current state of electronic scientific publications]. Informatsiini tekhnolohii $i$ zasoby navchannia [Information technologies and educational tools], no 3. Available at: http://www.ime.edu-ua.net/em3/emg.html

24. Zhaldak M.I. (2003). Pedahohichnyi potentsial kompiuterno-oriientovanykh system navchannia matematyky [Pedagogical Potential of Computer-Aided Mathematics Learning Systems]. Kompiuterno-oriientovani systemy navchannia [Computer-oriented systems of learning]. Kyiv: NPU M.P. Drahomanova, vol. 7, pp. 3-16.

25. Zhevankina N.V. (2009). Pedahohichni umovy orhanizatsii dystantsiinoho navchannia studentiv humanitarnykh spetsialnostei $u$ pedahohichnykh universytetakh [Pedagogical conditions for the organization of distance learning of students of humanities in pedagogical universities] (Phd Thesis), Luhansk. 